\title{
Small ruminant lentiviruses: economic and productive losses, consequences of the disease
}

\author{
Lentiviroses de pequenos ruminantes: perdas produtivas \\ e econômicas, consequências da doença
}

\begin{abstract}
Dalva Alana Aragão de Azevedo ${ }^{\text {* }}$, Vanderlan Warlington Souza dos Santos², Ana Lídia Madeira de Sousa', Renato Mesquita Peixoto', Raymundo Rizaldo Pinheiro ${ }^{3}$, Alice Andrioli ${ }^{3}$, Maria Fátima da Silva Teixeira'
\end{abstract}

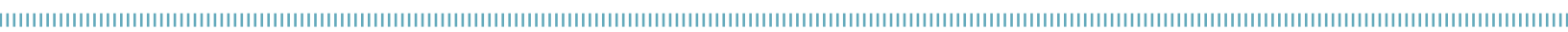

\begin{abstract}
Small ruminant lentiviruses, caprine arthritis encephalitis virus, and Maedi-Visna virus cause diseases that result in significant productive losses, mostly in dairy animals. These viruses belong to the Retroviridae family, Lentivirus genus, and constitute a heterogeneous group, which may generate implications for the diagnosis and control of small ruminant lentiviruses. Losses caused by them are associated with reproductive failure, short productive life, and decreased milk production by the infected animals. In addition, these viruses may reduce milk quality, affecting the production of dairy products such as cheese. Small ruminant lentiviruses lead to indirect losses, decreasing herd value and forcing the development of epidemiological trade barriers for animal germplasm. Control of small ruminant lentiviruses is important to promote optimal milk production and to reduce costs with medicine and technical assistance. This control may vary in caprine and ovine populations of each country, according to seroprevalence, variety of breeds, and peculiarities of the practiced management.
\end{abstract}

KEYWORDS: production losses; small ruminant lentiviruses; control.
RESUMO: Os lentivírus de pequenos ruminantes, o vírus da artrite encefalite caprina e o vírus Maedi-Visna causam enfermidades que ocasionam perdas produtivas significativas, principalmente em animais com aptidão leiteira. Esses vírus pertencem à família Retroviridae e ao gênero Lentivirus e formam um grupo genético heterogêneo, o que pode ocasionar implicaçóes para o diagnóstico e o controle dos lentivírus de pequenos ruminantes. As perdas causadas pelos lentivírus de pequenos ruminantes estão relacionadas com falhas reprodutivas, vida produtiva curta e diminuição da produção leiteira dos animais infectados. Além disso, esses vírus podem promover a redução da qualidade do leite, afetando a produçáo de laticínios, tal como o queijo. Os lentivírus de pequenos ruminantes levam a perdas indiretas, reduzindo o valor dos rebanhos e forçando o desenvolvimento de barreiras comerciais epidemiológicas para germoplasma animal. O controle dos lentivírus de pequenos ruminantes é importante para promover uma maior produção de leite e reduzir os custos com medicamentos e assistência técnica. Esse controle pode variar de acordo com a população caprina e ovina de cada país em termos de soroprevalência, variedade de raças e particularidades do manejo adotado.

PALAVRAS-CHAVE: perdas produtivas; lentivírus de pequenos ruminantes; controle.

\footnotetext{
'Universidade Estadual do Ceará (UECE) - Fortaleza (CE), Brazil.

${ }^{2}$ Universidade Federal Rural do Semiárido (UFERSA) - Mossoró (UF), Brazil.

${ }^{3}$ Embrapa Caprinos e Ovinos - Sobral (UF), Brazil.

*Corresponding author: dalvaazevedo@outlook.com

Received on: 07/25/2016. Accepted on: 10/19/2017
} 


\section{INFECTION AND DIAGNOSTIC METHODS}

Small ruminant lentivirus (SRLV) infections, which are caprine arthritis encephalitis (CAE) and Maedi-Visna (MV), are important diseases in sheep and goat productions. There are four main clinical presentations: arthritis, respiratory, mammary, and neurological. In addition, these diseases cause progressive weight loss that result in significant economic losses (PUGH, 2004; BRITO, 2009).
Causative agents of these diseases are SRLV, which were originally designated as CAE and MV viruses. These pathogens have been isolated in different countries, including Brazil, and many studies identified these diseases in different Brazilian regions with varied levels of seroprevalence (Figs. 1 and 2).

According to the International Committee on Taxonomy of Viruses, SRLV belong to the Retroviridae family, sub-family Orthoretrovirinae, Lentivirus genus. SRLV are divided into five groups named A-E. Group A

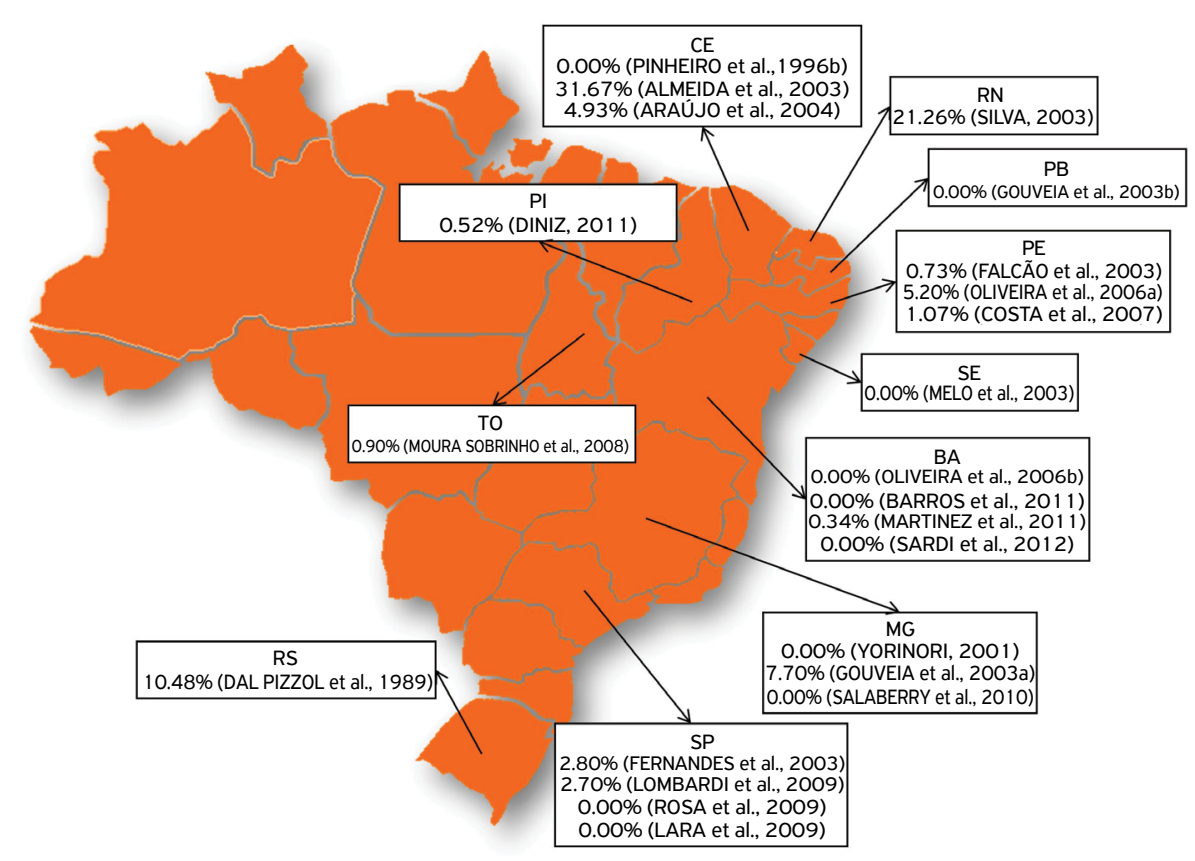

Source: SOUZA (2014).

Figure 1. Seropositivity for lentiviruses of small ruminants in sheep from different states in Brazil.

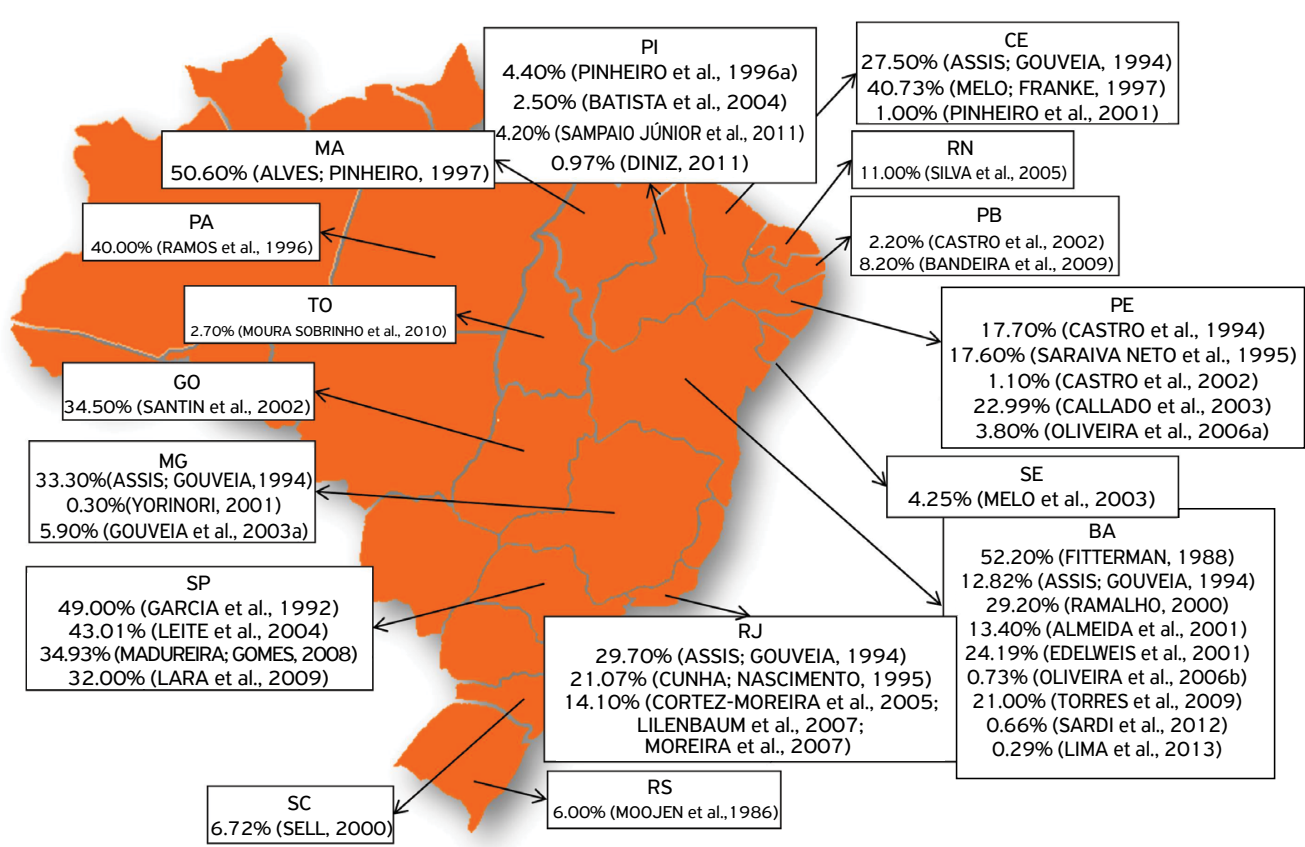

Source: adapted from LIMA et al. (2013).

Figure 2. Seropositivity for lentiviruses of small ruminants in goats from different states in Brazil. 
is subdivided into 15 subtypes $\mathrm{A} 1-\mathrm{A} 15$, and group $\mathrm{B}$ into three subtypes B1, B2, and B3. A low number of isolates comprise the groups $\mathrm{C}$ and $\mathrm{D}$, while group $\mathrm{E}$ has subtypes E1 and E2 (SHAH et al., 2004; GREGO et al., 2007; GJERSET et al., 2007; PISONI et al., 2010; REINA et al., 2010; BERTOLOTTI et al., 2011; GIAMMARIOLI et al., 2011; FRAS et al., 2013; KUHAR et al., 2013). These viruses form a heterogeneous genetic group, and this difference in their genetic composition has practical implications for the sensitivity and specificity of diagnostic tests. In addition, control and eradication programs applied in infected flocks face severely challenges by these characteristics (PASICK, I 998).

Target cells for small ruminant lentiviruses are monocytes/ macrophages, which are defense cells found in the organisms of animals (NARAYAN et al., 1982). These viruses may be found in a high concentration in infected tissues and fluids, even in tissues that are not usually a preference for viral replication. The presence of SRLV has been identified in blood, colostrum and milk (LARA et al., 2003), cerebrospinal fluid (SIDER et al., 2010), uterine fluid and semen (ANDRIOLI, 2001; ANDRIOLI et al., 2006). In addition, these pathogens have been identified directly or indirectly in third eyelid tissue (CAPUCCHIO et al., 2003), goat epithelial cells of oviduct (LAMARA et al., 2002), uterine tissue (FIENI et al., 2003), mammary gland (LERONDELLE et al., 1999), and lung (BARROSO, 2013). These viruses have been identified in the central nervous system (SANNA et al., 1999), stromal cells of bone marrow in fibrocytes, endothelial cells and adipocytes (GROSSI et al., 2005).

Viral transmission occurs directly or indirectly by secretions rich in cells of the monocyte/macrophage system, especially macrophages. The main form of transmission is digestive, through the ingestion of colostrum and/or milk of infected goats and sheep. The aerosolized transmission is very important for MV, considering that the main form of clinical disease is respiratory (DAWSON, 1987; MOOJEN, 2001). In addition, direct transmission may occur through the reflux of contaminated milk in deregulated milking machine, contaminated fomites, such as towels, needles, tattoo and dehorning equipment (ROWE; EAST, 1997) or artificial insemination (SOUZA et al., 2013). Intrauterine transmission has not been discarded yet (ALVES, 2015). Interspecies transmission of SRLV is mainly through the contact of infected sheep and goats and by the ingestion of contaminated colostrum or milk of infected goat nannies (SOUZA et al., 2015b). In 2015, SOUZA et al. (2015a) demonstrated the virus in saliva, which may play an important role in the epidemiology of the disease if it is infectious.

SRLV may be detected directly or indirectly. Among the detection methods, viral isolation in cellular culture, electronic microscopy, in situ hybridization and polymerase chain reaction tests are direct forms. Indirect methods are performed with the detection of antibodies in serological tests. The most frequently used serological techniques for diagnosing SRLV infections are agarose gel immunodiffusion (AGID), indirect immunofluorescence assay (IFA), immunohistochemistry, and immunoassays: Enzyme-linked Immunosorbent Assay (ELISA), Dot-Blot, and Western Blot (WB). The AGID is a practical test with low cost and one of the indicated methods by the World Organization for Animal Health (OIE). It is used in screening, considering the acceptable sensitivity and excellent specificity it presents. However, it fails to detect animals with low titers of antibodies, allowing the occurrence of false-negative individuals within the flock. As a result, the virus is maintained and transmitted from positive animals that were not identified to healthy individuals (ANDRÉS et al., 2005; RODRIGUES et al., 2014; PINHEIRO et al., 2012).

PINHEIRO et al. (2012) evaluated the sensitivity of AGID, ELISA and WB with a serial dilution of SRLV-positive serum and verified that AGID presented detectable precipitation line up until 1:8 dilution. Positive results were identified with ELISA up to 1:64 and with WB until 1:1024. These data demonstrate that WB may detect antibodies in a dilution 128 times higher than AGID and 16 times higher than ELISA.

SRLV infection usually presents a long period of incubation with frequent occurrence of asymptomatic infections on top of diagnostic limitations. These happen due to genetic and antigenic relations of SRLV, which allow the occurrence of false-negative animals in flocks. These characteristics are limiting factors for controlling SRLV diseases, which lead to significant economic losses, mainly in dairy production. In addition, SRLV may migrate to several different tissues and fluids, hindering the detection and favoring transmission (PISONI et al., 2007), including interspecies (SOUZA et al., 2015b).

\section{ECONOMIC AND PRODUCTIVE LOSSES}

These diseases cause direct losses, such as decrease in the productive life length and milk production; shorter duration of lactating period; predisposal for bacterial infections especially in the mammary gland; and reduction in fat and protein levels of milk produced by the infected goats, which affect dairy products such as cheese production (SMITH; CUTLIP, 1988; GREGORY et al., 2009; BRITO, 2009; MARTÍNEZ-NAVALÓN et al., 2013). Indirect losses are associated with flock devaluation and commercial barriers for transport of animals and germplasm, such as nannies, bucks, semen, and embryos (PINHEIRO et al., 2001; MODOLO et al., 2003).

Among the clinical presentations of lentivirus infections, arthritis is usually described for the CAE, which is more frequently observed in animals older than eight months old (CRAWFORD; ADAMS, 1981). Joint lesions may impair 
regular grazing leading to weight loss and incapacitating bucks of performing natural mating (PINHEIRO et al., 1999). Other studies demonstrated the increase in the joint size of SRLV infected animals (JUTILA, 1987; BRODIE et al., 1998; GREENWOOD, 1995; PINHEIRO et al., 2005; ABREU et al., 2010).

The respiratory clinical presentation is commonly observed in sheep with MV disease. A study performed in Spain showed that the main source of sheep discard was due to respiratory and neurological conditions (BENAVIDES et al., 2013). Reinstating this fact, infected animals were estimated to be discarded a year earlier than healthy animals (PETERHANS et al., 2004). The early loss of young animals causes an economic impact considering that one to three year-old animals present the best performance in production and cannot be easily replaced (PEREZ et al., 2010). According to Snowder et al. (1990a), sheep with subclinical infection by MVV do not present economic effects in wool production.

The effects in the mammary gland are the most important, considering that they affect milk production and predispose animals to secondary infections in this organ (SMITH; CUTLIP, 1988). Lentivirus infections may cause diffuse hardening of the mammary gland, even when microbial pathogens are not isolated from milk (BOHLAND; D'ANGELINO, 2005). LARA et al. (2005) consider interstitial mastitis a marked, hardening and frequent condition in dairy goat flocks. In addition, BENAVIDES et al. (2013) observed alterations in the mammary gland of dairy sheep diagnosed with MV, such as moderate to severe infiltration of lymphocytes, macrophages and plasma cells in the glandular parenchyma, as well as periductal hyperplasia of lymphoid follicles.

In general, seronegative sheep for MVV tend to produce more milk than seropositive sheep (SNOWDER et al., 1990b). The same occurs with goat nannies infected by CAE, which present a decrease in milk production and are more affected by health issues, besides reproductive problems. According to GREENWOOD (1995), seropositive multiparous goats presented an average reduction of $88 \mathrm{~kg}$ of milk production and 21 days of production in lactating period when compared with seronegative goats.

Other studies also identified a reduction in the milk production of dairy goats positive for SRLV, as observed by KRIEG; PETERHANS (1990), in which a decrease of approximately $10 \%$ was identified. BOHLAND; D'ANGELINO (2005) compared positive goat flocks with negatives and verified a reduction of 37 days in the lactating period and $94.6 \mathrm{~L}$ $(21.5 \%)$ in total milk production per lactation. Moreover, a study performed with dairy goat flocks in a semi-arid region of Ceará, Brazil, reported an even higher reduction of the milk production estimated in 26\% (BRITO, 2009). Based on MARTÍNEZ-NAVALÓN et al. (2013), milk production in seropositive animals decreases with the increase of age.
In the environmental conditions of the semi-arid region in Ceará, Brazil, CAE may cause significant losses in the income of milk production by mixed-breed goats. A loss in milk production of 20 infected animals in the 210 days of lactation was $\mathrm{R} \$ 938.28-406 €$. Due to the low profit margin in milk production, the losses caused by disease may compromise profitability in the dairy goat production (CARNEIRO et al., 2011).

In addition to milk production, some studies demonstrate that a reduction in milk quality occurs and levels of fat, protein, lactose and total solids may be reduced. Some physical factors such as electroconductivity and chloride contents are higher in the milk of infected goats. Moreover, there is an increase in the somatic cell count (SMITH; CUTLIP, 1988; SANCHEZ et al., 2001; BIRGEL JUNIOR et al., 2007; BRITO, 2009; MARTÍNEZ-NAVALÓN et al., 2013).

Corroborating with the referenced literature, KABA et al. (2012) concluded that the milk of infected goat nannies has low levels of total protein ( 3.40 versus $3.35 \%, p \leq 0.01$ ), fat (3.69 versus $3.54 \%, \mathrm{p} \leq 0.01)$ and lactose ( 4.30 versus $4.25 \%$, $\mathrm{p} \leq 0.01$ ). However, BRITO (2009) verified a $5 \%$ reduction in fat levels and 3\% in total solids of seropositive goat milk and an increase of $32 \%$ in somatic cell count. TURIN et al. (2005) evaluated CAE effects in the production and biochemical components of milk produced by primiparas goat nannies and verified that milk production was similar among seropositive and seronegative individuals, and there was no significant difference in lactose values. However, levels of fat, protein and somatic cell count were statistically different. These studies indicate that the infection may interfere in milk quality, which might affect the production of dairy products.

CARNEIRO et al. (2011), after studying the effects of SRLV in dairy goat flocks, evaluated the influence of the disease in parasite infection and verified that goat nannies from seropositive group needed deworming more frequently than seronegative females, which were more intense at the end of rainy season and in peripartum. Gastrointestinal parasite infection associated with CAE elevated $60 \%$ of the costs with deworming drugs, and primiparas were mostly affected. Seropositive group presented higher cost values related to anthelmintic drugs and laborin $€ \$ 29.60$ and $€ \$ 34.53$, respectively, when compared with the seronegative group. The authors concluded that such disease predisposes animals to gastrointestinal parasite infections; therefore, they raise costs of production with CAEV infected animals.

Infected animals are more susceptible to health issues than seronegative animals, such as peripartum udder edema, mastitis and enlargement of carpal joint, in addition to altered reproductive parameters. According to GREENWOOD (1995), among multiparous goat nannies, seropositive animals presented a higher rate of reproductive failure $(43 \%)$ in comparison with seronegative ones (18\%). However, there is no statistical difference in primiparas goat nannies. In the same 
study, the disease reduced in $5.6 \%$ the average weight of newborn goat kids.

The severe losses justify the control of lentivirus infections. Therefore, the application of prevention/control measures are suggested to minimize losses and promote optimal economic gain. Moreover, control measurements improve animal welfare, considering the obvious relation with disease and suffering (MURI et al., 2016). The use of control or eradication programs promotes decrease in seroprevalence to satisfactory levels and improves production and animal welfare consequently (PÉREZ et al., 2013).

\section{CONSIDERATIONS ON CONTROL MEASURES}

We suggest that disease control promotes improvement in milk production and quality, feed conversion and animal welfare, in addition to reducing costs with drugs and technical assistance. However, the producer should analyze the cost-benefit ratio for starting a program, considering that the necessary measures for control, and especially eradication, are expensive and laborious.

A major success in eradicating CAE was described in Japan, in which a series of measures against this disease was adopted between 2002 and 2006. The program used three strategies. Firstly, removal of goat kids immediately after birth; secondly, isolation of each generation; and thirdly, periodical discard of positive goats (AGID and PCR). After four generations, this set of measures promoted the transformation of infected goat flocks into CAEV-free and increased the milk production (KONISHI et al., 2011).

SRLV control is yet a problem for several producers due to the lack of communication regarding information generated by the scientific community to this audience. In addition, according to REINA et al. (2009), many countries have caprine and ovine populations with heterogeneous seroprevalence and a variety of breeds, environmental conditions and management particularities. Therefore, each country or region may need different control strategies. The situation in Brazil fits perfectly within this perspective. These issues prevent the implementation of a single political or control strategy as a reference that aims to minimize losses caused by lentivirus infections.

\section{CONCLUSION}

This study aimed to gather general aspects of SRLV, causative agents, and implications of these pathogens in the productive and economic aspects consequently. Although several studies have reported losses caused by SRLV, there is still a lack of data to assess the real costs for the application of control measures.

\section{REFERENCES}

ABREU, D.A.; ANDRIOLI, A.; BRITO, R.L.L.; ÁVILA, A.A.; PINHEIRO, R.R.R.; SOUZA, K.C. Avaliação da massa corporal e do índice articular clínico em caprinos portadores do vírus da artrite encefalite caprina (CAEV). In: CONGRESSO NORDESTINO DE PRODUÇÃO ANIMAL, 6., 2010, Mossoró. Anais... Mossoró: Sociedade Nordestina de Produção Animal; UFERSA, 2010. 1 CD-ROM.

ALMEIDA, M.G.A.R.; ANUNCIAÇÃO, A.V.M.; FIGUEIREDO, A. MARTINEZ, T.C.N.; LABORDA, S.S. Dados sorológicos sobre a presença e distribuição da artrite encefalite caprina (CAE) no Estado da Bahia, Brasil. Revista Brasileira de Saúde e Produção Animal, v.1, n.3, p.78-83, 2001.

ALVES, F.S.F.; PINHEIRO, R.R. Presença da artrite encefalite caprina a vírus (CAEV) no estado do Maranhão. In: CONGRESSO BRASILEIRO DE MEDICINA VETERINÁRIA, 25., 1997, Gramado. Anais... Gramado: Sociedade Brasileira de Medicina Veterinária, 1997. p.278.

ALVES, R.P.A. Artrite encefalite caprina: comparação entre técnicas diagnósticas e estudo da transmissão vertical entre animais soronegativos. 72f. Dissertation (Mestrado em Ciência Animal) Universidade Federal do Piauí, Teresina, 2015.

ANDRÉS, D.; KLEIN, D.; WATT, N.J.; BERRIATUA, E; TORSTEINSDOTTIR, S.; BLACKLAWS, B.A.; HARKISS, G.D. Diagnostic test for small ruminant lentiviruses. Veterinary Microbiology, v. 107, p.49-62, 2005.

ANDRIOLI, A. Vírus da artrite encefalite caprina: PCR e isolamento viral em amostras de semen, fluido uterino e embriões. 68p. Thesis (Doutorado em Ciência Animal) - Universidade Federal de Minas Gerais, Belo Horizonte, 2001.

ANDRIOLI, A.; GOUVEIA, A.M.G.; MARTINS, A.S.; PINHEIRO, R.R.; SANTOS, D.O. Fatores de risco na transmissão do lentivírus caprino pelo sêmen. Pesquisa Agropecuária Brasileira, v.41, n.8, p.1313-1319, 2006.

ASSIS, A.P.M.V.; GOUVEIA, A.M.G. Evidências sorológicas de lentivírus (Maedi-Visna/artrite-encefalite caprina) em rebanhos nos estados de MG, RJ, BA e CE. In: CONGRESSO BRASILEIRO DE MEDICINA VETERINÁRIA, 23., 1994, Olinda. Anais... Olinda: Sociedade Pernambucana de Medicina Veterinária, 1994. p.104. 
BANDEIRA, D.A.; CASTRO, R.S.; AZEVEDO, E.O.; MELO, L.S.S.; MELO, C.B. Seroprevalence of caprine arthritis-encephalitis virus in goats in the Cariri region, Paraiba state, Brazil. The Veterinary Journal, 2009.

BARROS, I.N.; SILVA, N.S.; ALMEIDA, M.G.A.R.; ANUNCIAÇÃO, A.V.M.; LABORDA, S.S.; RAMALHO, E.J.; OLIVEIRA, E.M.D. Detection of antibodies to Visna/Maedi in sheep from Recôncavo Baiano. Revista de Ciências Agrárias, v.53, n.2, p.206-211, 2011.

BARROSO, I.C. Estudo analítico morfológico de pulmões ovinos infectados pelo vírus Maedi-Visna. 60f. Dissertation (Mestrado em Ciências Veterinárias) - Universidade Estadual do Ceará, Fortaleza, 2013.

BATISTA, M.C.S.; CASTRO, R.S.; CARVALHO, F.A.A.; CRUZ, M.S.P.; SILVA, S.M.M.S.; REGO, E.W.; LOPES, J.B. Anticorpos antilentivírus de pequenos ruminantes em caprinos integrantes de nove municípios piauienses. Ciência Veterinária nos Trópicos, v.7, n.2- 3, p.75-81, 2004.

BENAVIDES, J.; FUERTES, M.; GARCÍA-PARIENTE, C.; OTAOLA, J.; DELGADO, L.; GIRALDEZ, J.; MARÍN, J.F.G.; FERRERAS, M. C.; PÉREZ, V. Impact of Maedi-Visna in intensively managed dairy sheep. The Veterinary Journal, v.197, p.607-612, 2013.

BERTOLOTTI, L.; MAZZEI, M.; PUGGIONI, G.; CARROZZA, M.L.; DEI GIUDICI, S.; MUZ, D.; JUGANARU, M.; PATTA, C.; TOLARI, F.; ROSATI, S. Characterization of new small ruminant lentivirus subtype B3 suggests animal trade within the Mediterranean Basin. Journal of General Virology, v.92, n.8, p.1923-1929, 2011.

BIRGEL JUNIOR, E.H.; CESTARI, V.; SAMPAIO, R.M.; LARA, M.C.C.S.H.; BIRGEL, D.B.; RAIMONDO, R.F.S.; BRANDESPIN, F.B.; BIRGEL, E.H. Influência da infecção pelo vírus da artrite encefalite caprina nas características físico-químicas e celulares do leite de caprinos. Arquivos do Instituto Biológico, São Paulo, v.74, n.3, p.199-206, 2007.

BOHLAND, E.; D'ANGELINO, J.L. Artrite encefalite caprina: avaliação dos aspectos produtivos e reprodutivos de animais infectados e não infectados. Brazilian Journal of Veterinary Research and Animal Science, v.42, n.2, p.81-88, 2005.

BRITO, R.L.L. Implicações da artrite-encefalite caprina na reprodução, produção e na qualidade de leite de cabras. $109 \mathrm{f}$. Dissertation (Mestrado em Zootecnia) - Universidade Estadual Vale do Acaraú, Sobral, 2009.

BRODIE, S.J.; DE LA CONCHA-BERMEJILLO, A.; SNOWDER, G.D.; DEMARTINI, J.C. Current concepts in the epizootiology, diagnosis and economic importance of ovine progressive pneumonia in North America: a review. Small Ruminant Research, v.27, n. 1, p.1-17, 1998.

CALLADO, A.K.C.; FALCÃO, L.P.C.A.; CASTRO, R.S.; OLIVEIRA, E.J.C.; FALCÃO FILHO, M.C.A.; ARRUDA, E.T.; NASCIMENTO, S.A.; CAMPOS, K.M.T.; MELO, L.E.H.; MENEZES, V.L.M. Levantamento sorológico para CAE em caprinos leiteiros do estado de Pernambuco. In: CONGRESSO LATINOAMERICANO, 11., CONGRESSO BRASILEIRO, 5., CONGRESSO NORDESTINO DE BUIATRIA, 3., 2003, Salvador. Anais... 2003. p.50.

CAPUCCHIO, M.T.; SANNA, E.; SANNA, M.P.; FARIGU, S.; MINELLI, R.; GUARDA, F. Maedi-Visna Virus Detection in Ovine Third Eyelids. Journal of Comparative Pathology, v.129, p.37-43, 2003.
CARNEIRO, F.F.D.; BRITO, R.L.L.; SANTOS, V.W.S.; GOMES, T.C.L.; ANDRIOLI, A.; PINHEIRO, R.R. Perdas Econômicas Decorrentes da Artrite-Encefalite Caprina na Produção de Gordura e Sólidos Totais de Leite. Revista Científica de Produção Animal, v. 13, p.130-134, 2011.

CASTRO, R.S.; AZEVEDO, E.O.; TABOSA, I.; NASCIMENTO, S.A.; OLIVEIRA, M.M.M. Anticorpos para o vírus da artrite-encefalite caprina em animais sem raça definida (SRD) de abatedouros dos estados de Pernambuco e Paraíba. Ciência Veterinária nos Trópicos, v.5, n.2/3, p.121-123, 2002.

CASTRO, R.S.; NASCIMENTO, S.A. ABREU, S.R.O. Evidência sorológica da infecção pelo vírus da artrite-encefalite caprina em caprinos leiteiros do Estado de Pernambuco. Arquivo Brasileiro de Medicina Veterinária e Zootecnia, v.46, n.5, p.571-572, 1994.

CORTEZ-MOREIRA, M.; OELEMANN, W.M.R.; LILENBAUM, W. Comparison of serological methods for the diagnostic of caprine arthritis-encephalitis (CAE) in Rio de Janeiro, Brazil. Brazilian Journal of Microbiology, v.36, n. 1, p.48-50, 2005.

COSTA, L.S.P.; LIMA, P.P.; CALLADO, A.K.C.; NASCIMENTO, S.A.; CASTRO, R.S. Lentivírus de pequenos ruminantes em ovinos Santa Inês: Isolamento, identificação pela PCR e inquérito sorológico no estado de Pernambuco. Arquivos do Instituto Biológico, v.74, n. 1, p.11-16, 2007.

CRAWFORD, T.B.; ADAMS, D.S. Caprine arthritis-encephalitis: clinical features and presence of antibody in selected goat populations. Journal of the American Veterinary Medical Association, v.178, n.7, p.713-719, 1981.

CUNHA, R.G.; NASCIMENTO, M.D. Ocorrência de anticorpos para o vírus da artrite encefalite caprina em soros de caprinos do estado do Rio de Janeiro. Revista Brasileira de Medicina Veterinária, v.17, n.2, 1995.

DAL PIZZOL, M.; RAVAZZOLO, A.P.; GONÇALVES, I.P.D.; HÖTZEL, I.; FERNANDES, J.C.T.; MOOJEN, V. Maedi-Visna: Evidência de ovinos infectados no Rio Grande do Sul, Brasil, 1987-1989. Arquivos da Faculdade de Veterinária da UFRGS, v.17, p.65-76, 1989.

DAWSON, M. Pathogenesis of Maedi-Visna. The Veterinary Record, v.120, p.451-454, 1987.

DINIZ, B.L.M. Estudo zoosanitário da caprinocultura e da ovinocultura, e soroprevalência das lentiviroses de pequenos ruminantes na microrregião do Alto Médio Gurguéia, na região sul do Piauí, Teresina. 178f. Thesis (Doutorado) - Programa de Pós-Graduação em Ciência Animal da Universidade Federal do Piauí, Teresina, 2011.

EDELWEIS, G.; TIGRE, D.; NORONHA, R.; QUEIROZ, L.; CAMPOS, G.S.; SARDI, S.I. Ocorrência de anticorpos contra o vírus da Artrite Encefalite Caprina em caprinos jovens de diferentes municípios do estado da Bahia. In: CONGRESSO BRASILEIRO DE MEDICINA VETERINÁRIA, 28., 2001, Salvador. Anais... 2001.

FALCÃO, L.S.P.C.A.; CAMPOS, K.M.T.; CALLADO, A.K.C.; CASTRO, R.S.; OLIVEIRA, E.J.C.; FALCÃO FILHO, M.C.A.; NASCIMENTO, S.A.; MELO, L.E.H.; ARRUDA, E.T. Anticorpos contra lentivírus de pequenos ruminantes (CAEV e Maedi- Visna) em ovinos Santa Inês do estado de Pernambuco. In: CONGRESSO LATINOAMERICANO, 11., CONGRESSO BRASILEIRO, 5., CONGRESSO NORDESTINO DE BUIATRIA, 3., 2003, Salvador. Anais... 2003. p.50. 
FERNANDES, M.A.; ARAÚJO, W.P.; CASTRO, R.S. Prevalência da infecção pelo vírus Maedi-Visna em ovinos da microrregião da grande São Paulo, Estado de São Paulo. Ciência Veterinária nos Trópicos, v.6, n.1, p.23-28, 2003.

FIENI, F.; ROWE, J.; VAN HOOSEAR, K.; BURUCOA, C.; OPPENHEIM, S.; ANDERSON, G.; MURRAY, J.; BONDURANT, R. Presence of caprine arthritis-encefalitis virus (CAEV) proviral DNA in genital tracts tissues of superovulated dairy goat does. Theriogenology, v.59, p.1515-1523, 2003.

FITTERMAN, I.R. Constatação do complexo artrite-encefalite em um plantel de caprinos no Estado da Bahia. In: CONGRESSO BRASILEIRO DE MEDICINA VETERINÁRIA, 1988, Salvador. Anais... 1988. p.93.

FRAS, M.; LEBOEUF, A.; LABRIE, F.M.; LAURIN, M.A.; SINGH SOHAL, J.; L'HOMME, Y. Phylogenetic analysis of small ruminant lentiviruses in mixed flocks: multiple evidence of dual infection and natural transmission of types $\mathrm{A} 2$ and $\mathrm{B} 1$ between sheep and goats. Infection, Genetics and Evolution, v. 19, p.97-104, 2013.

GARCIA, M.; GALHARDO, M.; ARAÚJO, W.P.; D’ANGELINO, J.L; BASTOS, P.S.; ROSSINI, A.J. Caprine Arthritis-Encephalitis (CAE). Occurrence of positive sera in goats raised in Brazil. Tropical Animal Health Production, v.24, n.3, p.164, 1992.

GIAMMARIOLI, M.; BAZZUCCHI, M.; PUGGIONI, G.; BRAJON, G.; DEI GIUDICI, S.; TACCORI, F.; FELIZIANI, F.; DE MIA, GM. Phylogenetic analysis of small ruminant lentivirus (SRLV) in Italian flocks reveals the existence of novel genetic subtypes. Virus Genes, v.43, p.380-384, 2011.

GJERSET, B.; JONASSEN, C.M.; RIMSTAD, E. Natural transmission and comparative analysis of small ruminant lentiviruses in the Norwegian sheep and goat populations. Virus Research, v.125, n.2, p. 153-161, 2007.

GOUVEIA, A.M.G.; LIMA, F.A.; ABREU, C.P.; LOBATO, Z.I.P.; YORINORI, E.H.; CYPRESTE, B.M. Lentiviroses de pequenos ruminantes em ovinos e caprinos em Minas Gerais. In: CONGRESSO LATINOAMERICANO, 11 ., CONGRESSO BRASILEIRO, 5., CONGRESSO NORDESTINO DE BUIATRIA, 3., 2003, Salvador. Anais... 2003a. p.52.

GOUVEIA, A.M.G.; LIMA, F.A.; SOUSA, G.JG.; LOBATO, Z.I.P.; SILVA, A.H.; SILVA, M.A.V.; CYPRESTE, B.M. Frequência sorológica de Maedi-Visna, Língua Azul em ovinos, em propriedades e matadouro da Paraíba. In: CONGRESSO LATINOAMERICANO, 11., CONGRESSO BRASILEIRO, 5., CONGRESSO NORDESTINO DE BUIATRIA, 3., 2003, Salvador. Anais...2003b, p.52.

GREGO, E.; BERTOLOTTI, L.; QUASSO, A.; PROFITI, M.; LACERENZA, D.; MUZ, D.; ROSATI, S. Genetic characterization of small ruminant lentivirus in Italian mixed flocks: evidence for a novel genotype circulating in a local goat population. The Journal of General Virology, v.88, p.3423-3427, 2007.

GREGORY, L.; LARA, M.C.C.S.H.; VILLALOBOS, E.M.C.; HASEGAWA, M.Y.; CASTRO, R.S.; RODRIGUES, J.N.M.; ARAÚJO, J.; KELLER, L.W.; DURIGON, E.L. Detecção do vírus da artrite encefalite caprina em amostras de leite de cabras pela reação em cadeia da polimerase (PCR) e nested-PCR. Ars Veterinária, v.25, n.3, p. $142-146,2009$.
GREENWOOD, P.L. Effects of Caprine Arthritis-Encephalitis virus on productivity and health of dairy goats in New South Wales, Australia. Preventive Veterinary Medicine, v.1-2, n.22, p.71-87, 1995.

GROSSI, P.; GIUDICE, C.; BERTOLETTI, I.; CIOCCARELLI, G.; BROCCHI, E.; CAMMARATA, G.; GELMETTI, D. Immunohistochemical Detection of the p27 Capsid Protein of Caprine Arthritis-Encephalitis Virus (CAEV) in Bone-marrow Cells of Seropositive Goats. Journal of Comparative Pathology, v.133, p.197-200, 2005.

JUTILA, M.A. Altered macrophage function and the pathogenesis of caprine arthritis-encephalitis. Dissertation Abstracts Internacional, n.92, p.311, 1987.

KABA, J.; STRZALKOWSKA, N.; JÓŹWIK, A.; KRZYZEWSKI, J.; BAGNICKA, E. Twelve-year cohort study on the influence of caprine arthritis-encephalitis virus infection on milk yield and composition. Journal Dairy Science, v.95, p. 1617-1622, 2012.

KONISHI, M.; NAGURA, Y.; TAKEI, N.; FUJITA, M.; HAYASHI, K.; TSUKIOKA, M.; YAMAMOTO, T.; KAMEYAMA, K.; SENTSUI, H.; MURAKAMI, K. Combined eradication strategy for CAE in dairy goat farm in Japan. Small Ruminant Research, v.99, p.65-71, 2011.

KRIEG, A.; PETERHANS, E. Die caprine arthritis-encephalitis in der Schweiz: epidemiologische und klinische Untersuchungen. Schweizer Archiv fur Tierheilkunde, Zurich, v.132, p.345-352, 1990.

KUHAR, U.; BARLIC-MAGANJA, D.; GROM, J. Phylogenetic analysis of small ruminant lentiviruses detected in Slovenia. Veterinary Microbiology, v.162, n.1, p.201-206, 2013.

LAMARA, A.; FIENI, F.; MSELLI-LAKHAL, L.; TAINTURIER, D.; CHEBLOUNE, Y. Epithelial cells from goat oviduct are highly permissive for productive infection with caprine arthritisencephalitis virus. Virus Research, v.87, p.69-77, 2002.

LARA, M.C.C.S.H.; BIRGEL JUNIOR, E.H.; FERNANDES, M.A.; BIRGEL, E.H. Infecção experimental do vírus da artrite-encefalite dos caprinos em cabritos. Arquivos do Instituto Biológico, v.70, n. 1, p.51-54, 2003.

LARA, M.C.C.S.H.; BIRGEL JUNIOR, L.; GREGORY, E.H.B.; BIRGEL, E.H. Aspectos clínicos da artrite-encefalite dos caprinos. Arquivo Brasileiro de Medicina Veterinária e Zootecnia, v.57, n.6, p.736-740, 2005.

LARA, M.C.C.S.H.; CARDOSO, M.V.; VILLALOBOS, E.M.C.; CUNHA, E.M.S.; PAULIN, L.M.; CASTRO, V.; PIATTI, R.M.; NASSAR, A.F.C.; PITUCO, E.M.; NOGUEIRA, A.H.C.; GABRIEL, F.; CHIEBAO, D.P.; OKUDA, L.H. Ocorrência de lentiviroses (CAE e Maedi-Visna) em pequenos ruminantes criados na região sudoeste do estado de São Paulo. In: FEIRA INTERNACIONAL DE CAPRINOS E OVINOS, 6., 2009, São Paulo. Anais... 2009. CD-ROM.

LEITE, B.L.S.; MODOLO, J.R.; PADOVANI, C.R.; STACHISSINI, A.V.M.; CASTRO, R.S.; SIMÕES, L.B. Avaliação da taxa de ocorrência da artrite-encefalite caprina a vírus pelas regionais do escritório de defesa agropecuária do estado de São Paulo, Brasil, e seu mapeamento por meio de sistema de informações geográficas. Arquivos do Instituto Biológico, v.71, n.1, p.21-26, 2004.

LERONDELLE, C.; GODET, M.; MORNEX, J.F. Infection of primary cultures of mammary epithelial cells by small ruminant lentiviruses. Veterinary Research, n.30, v.5, p.467-474, 1999. 
LILENBAUM, W.; SOUZA, G.N.; RISTOW, P.; MOREIRA, M.C.; FRÁGUAS, S.; CARDOSO, V.S.; OELEMANN, W.M.R. A serological study on Brucella abortus, caprine arthritis-encephalitis vírus and Leptospira in dairy goats in Rio de Janeiro, Brazil. The Veterinary Journal, n. 173, p.408-412, 2007.

LIMA, C.C.V.; COSTA, J.N.; SOUZA, T.S.; MARTINEZ, P.; COSTA NETO, A.O.; ANUNCIAÇÃO, A.V.M.; ALMEIDA, M.G.Á.R.; ARAÚJO, B.R.; PINHEIRO, R.R. Inquérito soroepidemiológico do lentivírus caprino e perfil das criações de caprinos na região do Baixo Médio São Francisco (BA). Arquivos do Instituto Biológico, São Paulo, v.80, n.3, p.288-296, 2013.

LOMBARDI, A.L; NOGUEIRA, A.H.C.; FERES, F.C.; PAULO, H.P.; CASTRO, R.S.; FEITOSA, F.L.F.; CADIOLI, F.A.; PEIRÓ, J.R.; PERRI, S.H.V.; LIMA, V.F.M.; MENDES, L.C.N. Soroprevalência de Maedi-Visna ovinos na região de Araçatuba, SP. Arquivo Brasileiro de Medicina Veterinária e Zootecnia, v.61, n.6, p.1434-1437, 2009.

MADUREIRA, K.M.; GOMES, V. Prevalência da Artrite Encefalite Caprina (CAE) em propriedades leiteiras do Estado de São Paulo. Revista de Ciências Veterinárias, v.5, p.86-90, 2008.

MARTINEZ, P.M.; COSTA, J.N.; SOUZA, T.S.; LIMA, C.C.V.; COSTA NETO, A.O.; PINHEIRO, R.R. Prevalência sorológica da Maedi-Visna em rebanhos ovinos da Microrregião de Juazeiro - Bahia por meio do teste de imunodifusão em gel de ágar. Ciência Animal Brasileira, Goiânia, v.12, n.2, p.322-329, 2011.

MARTÍNEZ-NAVALÓN, B.; PERIS, C.; GÓMEZ, E.A.; PERIS, B.; ROCHE, M.L.; CABALLERO, C.; GOYENA, E.; BERRIATUA, E. Quantitative estimation of the impact of caprine arthritis encephalitis virus infection on milk production by dairy goats. The Veterinary Journal, v.197, p.311-317, 2013.

MELO, A.C.M.; FRANKE, C.R. Soroprevalência da infecção pelo vírus da artrite-encefalite caprina (CAEV) no rebanho de caprinos leiteiros da Grande Fortaleza, Ceará, Brasil. Revista Ciência Rural, v.27, n. 1, p. $113-117,1997$.

MELO, C.B.; CASTRO, R.S.; OLIVEIRA, A.A.; FONTES, L.B.; CALLADO, A.K.; NASCIMENTO, S.A.; MELO, L.E.H.; SILVA, J.S. Estudo preliminar sobre a infecção por lentivírus de pequenos ruminantes em ovinos e caprinos em Sergipe. In: CONGRESSO LATINOAMERICANO, 11., CONGRESSO BRASILEIRO, 5., CONGRESSO NORDESTINO DE BUIATRIA, 3., 2003, Salvador. Anais... 2003. p.47.

MODOLO, J.R.; TACHISSINI, A.V.M.; CASTRO, R.S.; RAVAZZOLO, A.P. Planejamento de Saúde para o controle da Artrite-encefalite caprina. Botucatu: Cultura Acadêmica, 2003. 78p.

MOOJEN, V. Maedi-Visna dos ovinos. In: RIET-CORREA, F.; SCHILD, A.L.; MENDEZ, M.D.C.; LEMOS, R.A.A. Doenças de Ruminantes $e$ Equinos. 2. ed. São Paulo: Varela, 2001. p.138-144.

MOOJEN, V.; SOARES, H.C.; RAVAZZOLO, A.P.; PIZZOL, M.; GOMES, M. Evidência de infecção pelo Lentivirus (Maedi-Visna/Artriteencefalite Caprina) em caprinos do Rio Grande do Sul, Brasil. Arquivos da Faculdade de Veterinária da UFRGS, Porto Alegre, v.14, p.77-78, 1986.

MOREIRA, M.C.; OELEMANN, W.M.R.; LILENBAUM, W. Dados sorológicos da artrite encefalite caprina no estado do Rio de Janeiro (BR) e avaliação do uso do índice clínico como ferramenta de diagnóstico. Revista Brasileira de Medicina Veterinária, v.29, n.2, 2007.

MOURA SOBRINHO, P.A.; FERNANDES, C.H.C.; RAMOS, T.R.R.; CAMPOS, A.C.; COSTA, L.M.; CASTRO, R.S. Prevalência e fatores associados à infecção por lentivírus de pequenos ruminantes em ovinos no estado do Tocantins. Ciência Veterinária nos Trópicos, v. 11, n.2/3, p.65-72, 2008.

MOURA SOBRINHO, P.A.; RAMOS, T.R.R.; FERNANDES, C.H.C.; CAMPOS, A.C.; COSTA, L.M.; CASTRO, R.S. Prevalência e fatores associados à infecção por lentivírus de pequenos ruminantes em caprinos no estado do Tocantins. Ciência Animal Brasileira, v. 11 , n. 1, p. 117-124, 2010.

MURI, K.; LEINE, N.; VALLE, P.S. Welfare effects of a disease eradication programme for dairy goats. Animal, n.10, v.2, p.333-341, 2016.

NARAYAN, O.; WOLINSKY, J.S.; CLEMENTS, J.E.; STRANDBERG, J.D.; GRIFFIN, D.E.; CORK, L.C. Slow virus replication: the role of macrophages in the persistence and expression of visna viruses of sheep and goats. Journal General Virology, v.59, p.345-356, 1982.

OLIVEIRA, B.F.L.; BERGAMASCHI, K.B.; CRUZ, M.H.C.; SANTOS, D.D.; CRUZ, A.D.; CRUZ, J.F. Prevalência de lentiviroses em rebanhos caprinos e ovinos na região sudoeste da Bahia. In: SEMINÁRIO DE INICIAÇÃO CIENTÍFICA DA UESC, 12., 2006, Ilhéus. Anais... 2006a. p.134-135.

OLIVEIRA, M.M.M.; CASTRO, R.S.; CARNEIRO, K.L.; NASCIMENTO, S.A.; CALLADO, A.K.C.; ALENCAR, C.S.A.; COSTA, L.S.P. Anticorpos contra lentivírus de pequenos ruminantes em caprinos e ovinos em abatedouros do estado de Pernambuco. Arquivo Brasileiro de Medicina Veterinária e Zootecnia, v.58, n.5, p.947-949, 2006b.

PASICK, J. Maedi-Visna virus and caprine Arthritis-Encephalitis virus: Distinct species or quasispecies and its implications for laboratory diagnoses. Canadian Journal Veterinary, v.62, p.241-244, 1998.

PÉREZ, M.; BIESCAS, E.; DE ANDRÉS, X.; LEGINAGOIKOA, I.; SALAZAR, E.; BERRIATUA, E.; REINA, R.; BOLEA, R.; DE ANDRÉS, D.; JUSTE, R.A.; CANCER, J.; GRACIA, J.; AMORENA, B.; BADIOLA, J.J.; LUJÁN, L. Visna/Maedi virus serology in sheep: Survey, risk factors and implementation of a successful control programme in Aragón. The Veterinary Journal, v.186, p.221-225, 2010.

PÉREZ, M.; MUÑOZ, J.A.; BIESCAS, E.; SALAZAR, E.; BOLEA, R.; DE ANDRÉS, D.; AMORENA, B.; BADIOLA, J.J.; REINA, R.; LUJÁN, L. Successful Visna/Maedi control in a highly infected ovine dairy flock using serologic segregation and management strategies. Preventive Veterinary Medicine, v. 112, n. 1, p.423-427, 2013.

PETERHANS, E.; GREENLAND, T.; BADIOLA, J.; HARKISS, G.; BERTONI, G.; AMORENA, B.; ELIASZEWICZ, M.; JUSTE, R.A.; KRASSNIG, R.; LAFONT, J.P.; LENIHAN, P.; PÉTURSSON, G.; PRITCHARD, G.; THORLEY, J.; VITU, C.; MORNEX, J.F.; PÉPIN, $M$. Routes of transmission and consequences of small ruminant lentiviruses (SRLVs) infection and eradication schemes. Veterinary Research, v.35, n.3, p.257-274, 2004. 
PINHEIRO, R.R.; ALVES, F.S.F.; GIRÃO, E.S.; MEDEIROS, L.P.; GIRÃO, R.N. Presença da artrite encefalite caprina a vírus (CAEV) em Teresina-PI. In: CONGRESSO BRASILEIRO DE MEDICINA VETERINÁRIA, 24., 1996. Goiânia. Anais... Goiânia: Sociedade Goiana de Medicina Veterinária, 1996a. p.161.

PINHEIRO, R.R.; ALVES, F.S.F.; SANTA ROSA, J.; GOUVEIA, A.M.G. Levantamento sorológico em ovinos para diagnóstico da MaediVisna em Sobral- Ceará. In: CONGRESSO BRASILEIRO DE MEDICINA VETERINÁRIA, 24., 1996, Goiânia. Anais... 1996b. p.161.

PINHEIRO, R.R.; ANDRIOLI, A.; SIDER, L.H.; SANTIAGO, L.B.; OLIVEIRA, E.L.; SOUSA, A.L.M.; ALVES, F.S.F.; CRUZ, J.C.M. Lentiviroses em Pequenos Ruminantes: Principais Métodos de Diagnóstico. Sobral: Embrapa Caprinos e Ovinos, 2012. 42p. (Documentos, 107).

PINHEIRO, R.R.; GOUVEIA, A.M.G.; ALVES, F.S.F. Prevalência da infecção pelo vírus da Artrite-Encefalite Caprina no Estado do Ceará, Brasil. Ciência Rural, v.31, n.3, p.449-454, 2001.

PINHEIRO, R.R.; GOUVEIA, A.M.G.; ALVES, F.S.F.; ANDRIOLI, A. Medidas carpo-metacarpianas como índice articular clínico em caprinos. Revista Brasileira de Medicina Veterinária, v.27, n.4, p. 170-173, 2005.

PINHEIRO, R.R.; GOUVEIA, A.M.G.; ANDRIOLI, A. Prevalência da Artrite Encefalite Caprina em reprodutores caprinos nas principais regiões leiteiras do Estado do Ceará. Revista Brasileira Reprodução Animal, v.23, n.3, p.421-423, 1999.

PISONI, G.; BERTONI, G.; MANAROLLA, G.; VOGT, H.R.; SCACCABAROZZI, L.; LOCATELLI, C.; MORONI, P. Genetic analysis of small ruminant lentiviruses following lactogenic transmission. Virology, v.407, n.1, p.91-99, 2010.

PISONI, G.; MORONI, P.; TURIN, L.; BERTONI, G. Compartmentalization of small ruminant lentivirus between blood and colostrum in infected goats. Virology, v.369, p.119-130, 2007.

PUGH, D.C. Clínica de ovinos e caprinos. São Paulo: Roca, 2004. 513p.

RAMALHO, E.J. Artrite-encefalite caprina - CAE: prevalência de anticorpos séricos em caprinos criados no Estado da Bahia. 109f. Thesis (Doutorado) - Faculdade de Medicina Veterinária e Zootecnia, Universidade de São Paulo, São Paulo, 2000.

RAMOS, O.S.; SILVA, A.C.S.; MONTENEGRO, A.J.D.; FREITAS, J.A.; WATANABE, N. A. Anticorpos para o Vírus da Artrite Encefálica no município de Castanhal - Pará. Revista de Ciências Agrárias, v.26, p.107-111, 1996.

REINA, R.; BERRIATUA, E.; LUJÁN, L.; JUSTE, R.; SÁNCHEZ, A.; DE ANDRÉS, D.; AMORENA, B. Prevention strategies against small ruminant lentiviruses: an update. The Veterinary Journal, v.182, n. 1, p.31-37, 2009.

REINA, R.; BERTOLOTTI, L.; GIUDICI, S.D.; PUGGIONI, G.; PONTI, N.; PROFITI, M.; PATTA, C.; ROSATI, S. Small ruminant lentivirus genotype $E$ is widespread in Sarda goat. Veterinary Microbiology, v.144, n. 1-2, p.24-31, 2010.

RODRIGUES, A.S.; BRITO, R.L.L.; PINHEIRO, R.R.; DIAS, R.P.; ALVES, S.M.; SOUZA, T.S.; SOUZA, K.C.; AZEVEDO, D.A.A.; ANDRIOLI,
A.; MAGALHÃES, D.C.T.; TEIXEIRA, M.F.S. Padronização do Elisa indireto e Western Blot para o diagnóstico da artrite-encefalite caprina. Arquivo Brasileiro de Medicina Veterinária e Zootecnia, v.66, n.2, p.417-424, 2014.

ROSA, E.P.; AMORIM, R.M.; FERREIRA, D.O.L.; CHIACCHIO, S.B.; MODOLO, J.R. Soroprevalência da pneumonia progressiva ovina (Maedi-Visna) na região de Botucatu, SP. Ciência Animal Brasileira, v.10, n.3, p.847-852, 2009.

ROWE, J.D.; EAST, N.E. Risk factors for transmission and methods for control of caprine arthritis-encephalitis virus infection. Veterinary Clinics of North America: Food Animal Practice, v.13, n. 1, p.35-53, 1997.

SALABERRY, S.R.S.; LARA, M.C.C.S.H.; PIATTI, R.M.; NASSAR, A.F.C.; CASTRO, J.R.; GUIMARÃES, E.C.; LIMA-RIBEIRO, A.M.C. Prevalência de anticorpos contra os agentes da Maedi-Visna e clamidofilose em ovinos no município de Uberlândia, MG. Arquivos do Instituto Biológico, v.77, n.3, p.411-417, 2010.

SAMPAIO JÚNIOR, A.; BATISTA, M.C.S.; CRUZ, M.S.P.; SILVA, R.A.B.; BONA NASCIMENTO, C.; WERNECK, G.L. Prevalência da infecção por lentivírus de pequenos ruminantes em caprinos em Teresina, Piauí. Arquivo Brasileiro de Medicina Veterinária e Zootecnia, v.63, n.3, p.757-760, 2011.

SANNA, E.; SANNA, M.P.; VITALI, C.G.; RENZONI, G.; SANNA, L.; SPANO, S.; ROSSI, G.; LEONI, A. Proviral DNA in the Brains of Goats Infected with Caprine Arthritis-encephalitis. Virus Journal Comparative Pathology, v.121, p.271-276, 1999.

SANCHEZ, A.; CONTRERAS, A.; CORRALES, J.C.; MARCO, J.C. Relationships between infection with caprine arthritis encephalitis virus, intramammary bacterial infection and somatic cell counts in dairy goats. Veterinary Record, v.148, n.23, p.711-714, 2001.

SANTIN, A.P.I.; BRITO, W.M.E.D.; REISCHAK, D.; BRITO, L.A.B. Artrite encefalite caprina: identificação de animais soropositivos no estado de Goiás. Ciência Animal Brasileira, v.3, n.1, p.67-71, 2002.

SARAIVA NETO, A.O.; CASTRO, R.S.; BIRGEL, E.H.; NASCIMENTO, S.A. Estudo soro-epidemiológico da artrite-encefalite caprina em Pernambuco. Pesquisa Veterinária Brasileira, v.15, p.121124, 1995.

SARDI, S.I.; SENA, G.S.R.; CAMPOS, G.S.; SANTOS, G.R.; MAIA NETO, A.L.; AVILA, L.N. Ocorrência de lentivírus de pequenos ruminantes no semiárido baiano e perfil da caprino/ovinocultura na região. Ciência Animal Brasileira, v. 13, n.4, p.494-503, 2012.

SELL, B.E. Prevalência de anticorpos para o vírus da artriteencefalite caprina em soros de caprinos no estado de Santa Catarina. 24f. Monograph (Postgraduate) - Centro de Ciências Agroveterinárias, Universidade do Estado de Santa Catarina, Santa Catarina, 2000.

SHAH, C.; BONI, J.; HUDER, J.B.; VOGT, H.R.; MÜHLHERR, J.; ZANONI, R.; MISEREZ, R.; LUTZ, H.; SCHÜPBACH, J. Phylogenetic analysis and reclassification of caprine and ovine lentiviruses based on 104 new isolates: evidence for regular sheep-to-goat transmission and worldwide propagation through livestock trade. Virology, v.319, n.1, p.12-26, 2004. 
SIDER, L.H.; BRITO, R.L.L.; VERAS, A.K.A.; RODRIGUES, A.S.; SOUZA, K.C.; OLIVEIRA, E.L.; ANDRIOLI, A.; PINHEIRO, R.R. Processamento de líquido céfalo-raquidiano para extração de RNA genômico do vírus da artrite-encefalite caprina e diagnóstico molecular por RT-nested PCR. Sobral: Embrapa Caprinos e Ovinos, 2010. 4p. (Comunicado Técnico, 114).

SILVA, J.B.A. Levantamento sorológico pelo teste de imunodifusão em gel de agarose (IDGA) da lentivirose ovina em rebanhos do Rio Grande do Norte, Brasil. 6Of. Dissertation (Mestrado) - Universidade Estadual do Ceará, Fortaleza, 2003.

SILVA, J.S.; CASTRO, R.S.; MELO, C.B.; FEIJÓ, F.M.C. Infecção pelo vírus da artrite encefalite caprina no Rio Grande do Norte. Arquivo Brasileiro de Medicina Veterinária e Zootecnia, v.57, n.6, p.727-731, 2005.

SMITH, M.C.; CUTLIP, R. Effects on infection with caprine arthritisencephalitis virus on milk production in goats. Journal American Veterinary Medical Association, v. 193, n. 1, p.63-67, 1988.

SNOWDER, G.D.; GATES, N.L.; GLIMP, H.A.; GORHAM, J.R. Prevalence and effect of subclinical ovine progressive pneumonia virus infection on ewe wool and lamb production. Journal of American Veterinary Medical Association, v. 197, p.475-479, 1990a.

SNOWDER, G.D.; GLIMP, H.A.; GATES, N.L.; GORHAM, J.R. Analysis of milk production and composition in ewes seropositive and seronegative for ovine progressive pneumonia virus. Sheep Research Journal, v.6, n.3, p.24-28, 1990b.

SOUZA, K.C.; ANDRIOLI, A.; SIDER, L.H.; PINHEIRO, R.R.; BEZERRA JUNIOR, R.Q.; PEIXOTO, R.M.; TEIXEIRA, M.F.S. Detecção de sequências do DNA proviral do vírus da Artrite Encefalite Caprina em saliva. Acta Scientiae Veterinariae, v.43, p.1266, 2015a.
SOUZA, K.C.; PINHEIRO, R.R.; SANTOS, D.O.; BRITO, R.L.L.; RODRIGUES, A.S.; SIDER, L.H.; PAULA, N.R.O.; AVILA, A.A.; CARDOSO, J.F.S.; ANDRIOLI, A. Transmission of the caprine arthritis-encephalitis virus through artificial insemination. Small Ruminant Research, v.109, n.2-3, p.193-198, 2013.

SOUZA, T.S. Transmissão interespécies de lentivírus de caprinos para ovinos. 123f. Thesis (Doutorado em Ciência Animal nos Trópicos) - Universidade Federal da Bahia, Salvador, 2014.

SOUZA, T.S.; PINHEIRO, R.R.; COSTA, J.N.; LIMA, C.C.V.; ANDRIOLI, A.; AZEVEDO, D.A.A.; SANTOS, V.W.S.; ARAÚJO, J.F.; SOUSA, A.L.M.; PINHEIRO, D.N.S.; FERNANDES, F.M.C.; COSTA NETO, A.O. Interspecific transmission of small ruminant lentiviruses from goats to sheep. Brazilian Journal of Microbiology, 2015b.

TORRES, J.A.; CAMPOS, G.S.; FREITAS, M.M.; BRANDÃO, C.F.L.; SARDI, S.I. Produção de antígeno viral para o diagnóstico da artrite-encefalite caprina utilizando um teste imunoenzimático (ELISA), Revista de Ciências Médicas e Biológicas, v.8, n.2, p. 107-114, 2009.

TURIN, L.; PISONI, G.; GIANNINO, M.L.; ANTONINI, M.; ROSATI, S.; RUFFO, G.; MORONI, P. Correlation between milk parameters in CAEV seropositive and negative primiparous goats during na eradication program in Italian farm. Small Ruminant Research, v.57, p.73-79, 2005.

YORINORI, E.H. Região mineira do nordeste: características dos sistemas de produção de pequenos ruminantes domésticos $e$ prevalências da artrite-encefalite caprina (CAE) e Maedi-Visna (MV) ovina, Minas Gerais. $113 \mathrm{f}$. Dissertation (Mestrado) - Universidade Federal de Minas Gerais, Belo Horizonte, 2001.

\section{ERRATUM / ERRATA}

Arquivos do Instituto Biológico, vol. 84, Small ruminant lentiviruses: economic and productive losses, consequences of the disease, http://dx.doi.org/10.1590/1808-1657000552016, inserção dos nomes completos dos autores.

No artigo Small ruminant lentiviruses: economic and productive losses, consequences of the disease, com número de DOI: http://dx.doi.org/10.1590/1808-1657000552016, publicado no periódico Arquivos do Instituto Biológico, 84:e0552016, na página 1:

Onde se lia:

"Dalva Azevedo ${ }^{*}$, Vanderlan Souza dos Santos ${ }^{2}$, Ana Sousa ${ }^{1}$, Renato Peixoto ${ }^{1}$, Raymundo Pinheiro ${ }^{3}$, Alice Andrioli ${ }^{3}$, Maria Fátima da Teixeira" ${ }^{1 "}$

Leia-se:

"Dalva Alana Aragão de Azevedo"*, Vanderlan Warlington Souza dos Santos², Ana Lídia Madeira de Sousa1 ${ }^{1}$, Renato Mesquita Peixoto $^{1}$, Raymundo Rizaldo Pinheiro ${ }^{3}$, Alice Andrioli ${ }^{3}$, Maria Fátima da Silva Teixeira ${ }^{1 "}$ 